\title{
Lumen
}

Selected Proceedings from the Canadian Society for Eighteenth-Century Studies

\section{England Imported into Late Eighteenth-Century La Rochelle: Economic Consumption and Paradoxes of Cultural Exchange}

\section{Robert James Merrett}

Volume 15, 1996

URI : https://id.erudit.org/iderudit/1012477ar

DOI : https://doi.org/10.7202/1012477ar

Aller au sommaire du numéro

Éditeur(s)

Canadian Society for Eighteenth-Century Studies / Société canadienne d'étude du dix-huitième siècle

ISSN

1209-3696 (imprimé)

1927-8284 (numérique)

Découvrir la revue

Citer cet article

Merrett, R. J. (1996). England Imported into Late Eighteenth-Century La Rochelle: Economic Consumption and Paradoxes of Cultural Exchange. Lumen, 15, 115-133. https://doi.org/10.7202/1012477ar 


\section{England Imported into Late Eighteenth-Century La Rochelle: Economic Consumption and Paradoxes of Cultural Exchange}

On April 14, 1786, the weekly paper, the Annonces, affiches, et avis divers de la généralité de la Rochelle, declared that L'Anglomanie, a 'petit Poëme très-agréable,' was for sale in city bookshops. ${ }^{1}$ The local poet, having dedicated his life to 'l'embellissement des jardins,' had written a 'critique de la monotonie de plusieurs jardins français et de la singularité de variété de ceux des Anglais, sur-tout de leurs imitateurs.' The paper underscores the anonymous poem's jokes at the expense of French imitation of English dress and coaches: the 'petit ouvrage' offers 'quelques plaisanteries sur nos modes nouvelles dans les habillemens \& dans les voitures.'

The announcement is complete in neither bibliographic detail nor poetic summary. The title is L'Anglomanie, Poëme sur les Modes, Prises des Anglois, dans les Jardins, dans les Habillemens. It was published at La Rochelle by P. L. Chauvet in 1785, having been composed in 1784 . The announcement says the poem satirizes French imitators of English modes, but it also applies Horatian and militant stances to the English to render them and their modes unworthy of imitation. Deriding imported consumer goods, the poem conveys the full range of imports, its scorn for anglomania ironically proving French susceptibility to English economic and aesthetic standards. Seeking to be urbane, the poet becomes angry, economic fear underlying his contempt for English modes. His mask of Horatian poise being ill-fitting, it exposes his illusion that France may import English producer goods and technology while rejecting its consumer modes. This illusion is exposed further by daily life as represented in La Rochelle's weekly newspaper. Far from aiming to degrade the poem on account of its contradictions, this article seeks to grasp what the contradictions add to our sense of English-French cultural relations in the eighteenth century: it does so by explicating them, contextualising the aesthetic sensibility that voices them, and historiciz- 
ing them through what the local press reveals about the economic ties between England and France.

In its unpaginated preface, $L^{\prime}$ Anglomanie holds that the French in their slavishness to English modes betray their cultural superiority. They are 'un peuple d'enfans' since no longer intent on exemplifying warfare and 'les Beaux Arts' to the world. Mere 'imitateurs des Anglois,' they import 'caprices' and 'folies,' epitomised by French women covering their faces with large English hats: they should, urges the poet, be objects of beauty instead of screening themselves with feathers, jewels and flowers. His objectification of women is more dubious in the light of his assertion that French and English people are incomparable, a categorical distinction his rhetoric invalidates.

Claiming that high-born Englishmen never attain true breeding, the poet avers that, if deep thinkers, they are dull conversationalists whereas French nobles are inevitably sensitive and affable.

Ah! jamais l'Anglois le mieux né.

(Magnifique, par vanité)

$\mathrm{Ne}$ fut aux François comparable:

$S$ 'il est chez eux de vrais penseurs,

Que de froids, de pésans railleurs! (5)

A French cavalier is faithful to 'Son Roi, sa belle \& son honneur' since he is naturally a model of royalist, sexual and manly virtue (5). The English are 'un peuple sauvage,/ Qui méprise tout l'univers,' their vanity blinding them to the world's diversity and pointing up France's inclusivity. But far from illustrating this cultural inclusivity, the poet reveals it to be fragile by insisting that, through their importation of clothes, horses, and leisure activities, the French mistakenly treat England as the cultural paradigm. His scorn for this paradigm makes him urge that French authors who promote English gardening are particularly deceived since English gardens embody ideas that are 'Sombres, rustiques, insensées' (6). His scorn produces an unsteady tone: 'chers Citadains' are 'Singes blasés de l'Angleterre' when planting dead trees and building stone ruins in conformity to English gardening theory. The tonal ambivalence heightens the poet's enmity to English aesthetics: built ruins may convince ninnies of time's power over life but gardens need not mediate this power, the world being full of mortal signs (14-15). Assuming that gardening modes are rendered distinct by nationalism, the poet holds that true Frenchmen must laugh at Englishmen made tearful by gloomy landscapes. To him, 'Exister, c'est jouir': nature upholds hedonism by hiding death from 'toute créature,' providence making hope 'adoucir nos maux divers' (16). To keep a blithe tone, the poet erases political and 
cultural history: he forgets the religious wars crucial to La Rochelle's past, ignores its Protestant community, and closes his mind to French pictorial enjoyment of romanesque ruins and death's-heads. Only thus can he say that emblems of the dead and damned make English gardens fearful and impracticable whereas French gardens are designed for pleasure and gallantry. The latter cost little and are plain and filled with flowers and mythical statues to promote courtship of refined women. Anglomanes who render nature oppressive by prizing its gloomy aspects are sinister, unfrench (17): they are enemies to France's courtly and sexual mores.

Since he both relishes a 'vie obscure,/ Mon Jardin fait avec mesure,/ un peu de goût, très-peu de frais' and attacks the taste for English gardens, the poet's nationalistic defence of custom falters. As his Horatian views unfold, he grows so repetitious and miscellaneous that his stance becomes vulnerable to irony. Deriding fast English horses and skinny English jockeys favoured by anglomanes, he celebrates slow mounts and plump servants (18). English horse-racing patronised by courtiers he equates with English gardening: both signify French cultural malaise. Defining utility as wholly separable from aesthetic modes, he urges his neighbours to copy English commerce, management of marine vessels, and agricultural stock-breeding:

Il ne faut jamais qu'en l'utile

Imiter l'Anglois indocile;/

Imitons-le dans ses travaux,

Pour le commerce \& la marine;

L'économie en ses Vaisseaux;

Dans son exacte discipline;

L'Agriculture, les Troupeaux:

Non dans les Jardins qu'il dessine,

Ni dans ses courses de chevaux. (21-22)

Yet fear of England's sea-power counters this advice: English naval strategy stems from imperial pride that aims to dictate to Europe on land as well as at sea. He consoles himself that England's 'délire' is so obvious that Europe will strike back with crushing military force. Not only does such militarism seem at odds with France's eagerness for peace and free-trade with England after the War of American Independence but it clashes with the poet's supposed Horatian quietude.

The retaliation impelling the poet saps his division of utility from aesthetics by forcing him to stretch his arguments against English culture. When declaring he will not copy the English in their gardens, clothes and banquets (24), he claims that such things are out of tune with 
reason and 'bienfaisante nature,' thereby bringing philosophical tenets to bear on aesthetic modes. He reveals the inadequacy of this move by asserting that England's cultural modes are marked by a 'Triste ombrage' typical of 'ses mines de charbon' (33), here linking consumer to producer goods, fashion to industrialism. His next move is as precarious: he insists that England lacks contemporary artists, alleging that since the time of Thornhill the nation has yielded no major painters or sculptors. He apologizes for this generalization by granting the legitimacy of French homage to Newton, Congreve, Pope and Hamilton. He also admits his strategy of displacement when he invokes England as France's vainest rival: he wants to save the 'patrie' by detaching her from English goods by 'mes peintures générales' (34). He next displaces English artistic practice by mocking its religious didacticism: English art preaches that 'les plus douces existences/ Menent aux plus affreux trépas!' (34-35), while French art implicitly grants the operation of divine inspiration without making 'nos Tonnans Prédicateurs' redundant. His final would-be displacement of English aesthetics is the claim that its gardening modes are not original: they hail from China, having been accidentally introduced into England by some lord bent on importing porcelain. In derision, the poet sneers at the sinuous orchards and feeble cascades of Chinese gardens (37). But, while he assigns English cultivation of Chinoiserie to a melancholy taste for detail, he traces French Chinoiserie to 'gaieté' and 'nouveauté,' implying that subservience to English taste is shallow and that France resists as it appropriates foreign culture.

Yet, when he returns to the topic of French women and English modes, the poet charges that they adopt them single-mindedly, thereby suggesting English cultural dominance. Urged by no 'loi somptuaire,' French women stop wearing diamonds when driving out, since they prefer plain English coaches; chariots gleaming with inlaid gold and decorated with 'chefs-d'oeuvres de Peinture' are out of favour (38). He regrets that French women no longer wear the luxurious cloths of France, Italy and Asia and that they buy the plain, white stuffs of 'nos voisins fameux' since this amounts to submitting 'notre génie' to English modes. His regrets imply that English modes dominate French manufacturers and importers. His ridicule of the taste displayed by French women riding out in darkly coloured, low-roofed English coaches while wearing huge, colourful hats undermines his distinction between English utility and French aesthetic sense because it mocks French exaggeration of English modes. If towering English 'coëffes' require women to put their chins on their knees as they ride out, such contortions let the poet say that English hats are made more ridiculous by French 'caprices' (39) and that former coaches were more comfortable than new ones based on 
English designs. The poet's anti-feminism here degrades the ideas of English utility and French aesthetics that he otherwise upholds.

Far from commenting on the Eden Treaty negotiations or reconciling his ideas of utility and aesthetics, the poet ends his work with images of naval power and imperial retaliation. Viewing the Charente fleet from his garden, he says that the naval force makes garden ornaments redundant since it carries war into England's ports and threatens her trading fleets (54). The 'tableau si vaste' in his garden which he enjoys 'à si peu de frais' shows that warlike images enrich his scenic backdrop. When he who upholds 'le vieux goût' in his hamlet and professes to be content with paintbrush, gun and good books, calls neighbours 'tristes singes' for ornamenting rivers, mountains and forests in the English manner (55), the gap between his social disaffection and Horatian resignation makes his militarism and unconcern for La Rochelle as port and city seem more incongruous.

Pour moi je saurai bien seul vivre,

Même être heureux dans mon hameau,

Avec mes crayons, ma plume, un bon livre;

Et toujours décidé de suivre

Le vieux goût, pour suivre le nouveau. (55)

Yet, when contextualised, the poet's inconsistencies yield insights into cultural exchange. He may not grant the unoriginality of his gardening ideas; he may not examine his economic assumptions; and he may merely posture when it comes to integrating utility and aesthetics. But since such displacements and gaps are ideological moves, they show how cultural exchange between France and England worked. L'Anglomanie is one among scores of texts which resisted the incursion of English aesthetic modes (Grieder 1985). Josephine Grieder does not treat the poem in her study of anglomania, but her composite definition of anglomanes as people who ride English horses, race them with imported jockeys and bet on their prowess as well as people who build English gardens indicates that the poet's anglophobia is typical and even wellgrounded (Grieder 13).

Just how conventional the poet is can be gauged by discussing an author likely to have informed his gardening ideas. This author is Françoise de Paul Latapie whose translation of Thomas Whately's Observations on Modern Gardening appeared in 1771, the year after he toured England's major gardens. Trained as a doctor in Paris, he became a horticulturalist and botanist who collected 5,000 plants from gardens in England, Italy and France - largely for their pharmaceutical properties. As a member of Bordeaux's Academy of Science and Letters, he was 
asked to design the city's municipal gardens (Bériac 641); as inspectorgeneral 'des arts et Manufactures de la Généralité de Guienne,' he was alert to the influx of English aesthetic and industrial ideas from noting the construction of English gardens at the châteaux du Bouilh and de Montaigne and surveying the region's textile industry, tanneries, forges, glassworks and faienceries (Bériac 648). The introduction and notes to L'Art De Former Les Jardins Modernes, Ou L'Art Des Jardins Anglois [Par Mr Whately] show that, if Latapie faulted modish imitation of English gardens, his scientific interest in herbal drugs induced him to appreciate the utilitarian as well as aesthetic aspects of English landscape gardening.

Latapie acknowledges that Frenchmen decry English gardens because they view them as ' 1 'effet de cette ridicule anglomanie qui fait tant de progrès en France' (ii). He upholds the truism that anglomanes are privileged people who unpatriotically claim that 'rien n'est parfait que ce qui vient d'Angleterre.' He elucidates this lack of patriotism when he remarks that anglomanes contend that the works of Congreve and Thornhill are superior to those of Molière and Le Brun, a remark that confirms how typically the Rochelais poet represents anglomania. Latapie further helps clarify the poet's conventionality when he probes how French visitors often resist English gardens: they find the gardens ridiculous because they are 'accoutumés à regarder les principes reçus comme des regles infaillibles, \& que les hommes remontent difficilement à la source de leurs jugemens' (iii). If adopting national stereotypes, Latapie applies a comparative analysis to French cultural assumptions. He treats the influence of Chinoiserie on English gardening by showing that it was mediated by Père Attiret, a French authority on the Chinese Emperor's garden. Thus, he avoids the poet's easy denigration of English modes. Latapie grants that the English sacrifice 'les graces à la profondeur' but weighs the gains of this sacrifice against the conventionality of French aesthetics (li). He stresses the gains by extending Whately's gothicism. Denying Whately's view that gothic churches need only be ornamental and seen from the outside, Latapie recalls Stowe's gothic temple the interior gloom of which matches its exterior style:

C'est une retraite dont le sombre, la tranquillité \& l'air antique sont le mérite, \& qui ne sauroit déplaire, comme lieu propre à la rêverie. J'aime à y trouver un autel, des vitraux, \& des bas-reliefs gothiques.

Although, like the Rochelais poet, Latapie thinks gothicism out of place 'dans une perspective riante \& variée' (155), he enjoys gothic buildings in sombre, solitary settings. His doubts about English gothicism stem from his sense of the indiscriminate landscape use of churches and 
cemeteries and from his view of English melancholy which the Rochelais poet seems to have shared:

leurs ouvrages, de quelque genre que ce soit, ont-ils toujours une teinte de noir, \& ressemblent plus ou moins à ces festins Egyptiens, où la tête de mort qu'on mettoit sur la table, jettoit le poison de la tristesse au milieu du plaisir \& de la gaîté... la gaîté franche du peuple François, quoique mêlée de beaucoup de légéreté, vaut encore mieux, ce me semble, que la triste profondeur Angloise. J'espere que nous imiterons nos voisins, en rappellant, comme eux, la belle nature dans nos jardins; mais que les cimetieres en seront bannis à jamais.

$(232-33$, sic)

Although Latapie and the poet adopt similar stances to the differing national temperaments, the former has a broader mind about cultural imitation.

The kind of cultural exchange that Latapie encouraged may be estimated from the review of a new edition of his translation of Whately which appeared in Bordeaux's daily paper on September 8, 1786 (Journal de Guienne, No. 250, pp. 999-1000). The review attacks the conventionality of French designers: it says they lack 'la hardiesse d'envisager un jardin comme un spectacle immense, dont les scenes variées doivent faire naître dans l'ame du spectateur des sensations diverses de plaisir, de mélancolie, d'admiration, d'étonnement \& même de terreur.' Unlike the 'froide symmétrie' and 'triste uniformité' of French garden design, the English manner consists 'à copier les effets les plus pittoresques de la nature, \& à varier les objets en les multipliant.' Indeed, English designers follow Poussin when they 'caractérisent plusieurs scenes de leurs jardins par des tombeaux ou des pyramides sépulchrales.' It is less important to this article that the review treats the aesthetic modes of English gardens positively than that it sees these modes as deriving from a French pictorial model.

The cultural exchange that Latapie favoured is evident in the manuscript journal of his visit to England. Here his broad-mindedness arises from an appreciation of the mutual ties between utility and aesthetics, as when he discusses urban planning. He finds London's boroughs more charming than Paris's because its streets are wider, its sidewalks more convenient, and its houses taller (1770: 19-20). Carriage traffic he thinks more dangerous in Paris (62). He finds it hard to get used to the ubiquitous coal dust in England but decides that English is superior to French coal on account of its durable and comfortable heat (86). Positive about the physical amenities of England, he is open-minded about its modes of dress. He dons plain English clothes so as not to appear a Frenchman when walking out: he enjoys wearing a cuffless shirt, a white cravat, grey 
wool stockings, and a brown suit without buttons on the pockets (34). At the opera in the Haymarket he confirms his sense that fashion is not limited by nationalism. He notices how much the English dress themselves 'à la françoise': in the gallery, there are few, if any, English hats; in the parterre, '[j]e n'ai vu comme à Paris que des coeffures boursoufflées, ou des toquets guindés sur une hauteur de cheveux crêpés' (45). If he tolerates the sharing of modes and fashions more than the Rochelais poet, Latapie does impose patriotic limits on cultural exchange. He promotes visits to England and close observation of English modes and manners, but he warns compatriots against residing there. Granting that many Frenchmen have settled in London, he denies that it has a French quarter and claims that anti-French stage satire reflects English distrust of the French as neighbours (156). Despite promoting industrial and economic exchanges between France and England, he fears that material assimilation endangers cultural integrity. If Latapie's call for cultural exchange clarifies the xenophobia of the Rochelais poet, his doubts about resettlement signify a wish to limit cultural exchange to a degree that history, as documented in the French press, challenges.

Latapie's openness to cultural exchange between England and France and his sense that economic and aesthetic forces are reciprocal make one question why the Rochelais poet minimizes local and international issues along with the relations between them. His poem ignores $\mathrm{La}$ Rochelle's decaying harbour, its lack of commercial and manufacturing operations, and its growing reliance on capital and other markets in Northern Europe. Neither does he mention the national government's harsh treatment of the city and the rivalry with other seaports which together caused La Rochelle to depend increasingly on the slave trade and to be vulnerable to economic factors beyond its influence. ${ }^{2}$

When the poet penned L'Anglomanie, France was eager for free-trade with England, but the latter, wanting to maintain trade restrictions so as to slow the French economy, opposed the commercial clauses in the Treaty of Versailles of 1783 (Christie 167). Yet, after the Eden Treaty was signed on 26 September 1786, it banned trade restrictions as a form of warfare, allowing nationals of each country to be trading residents in the other (Christie 18-19). A further result of the treaty was that France lowered excise duties on imported British hardware, cottons, woollens and cambrics, not foreseeing the flood of imports that mounted in mid-1787 and deepened the severe industrial depression of 1788 and 1789 (Doyle 87). However, courtiers who had profited from royal licenses to import English manufactured goods in defiance of the law early anticipated the harm the Eden Treaty might do. In the 1770s when official trade between France and England was low since France had banned British cottons, hosiery, leather goods, glassware and hardware and 
England had banned the importation of French cambrics, lawns, silkstockings and gloves, courtiers flourished by patronizing industries based on imported English technology the protection for which was abolished by the Eden Treaty (Horn 67-68). Yet the Rochelais poet reacts to neither the court's patronage of English industry nor the national government's failure to foresee that the balance of trade would rapidly turn to Britain's favour (Christie 194).

It is especially appropriate to historicize the Rochelais poet in terms of his local press when we take into account a letter which Latapie wrote to the publishers of the Journal de Guienne, the daily Bordeaux paper which began in 1784 (28 mars 1785, p. 845). The opening paragraph of this letter provides an apology for the documentary functions of the regional press which could be neither more comprehensive nor more authoritative:

Le titre seul de votre Journal indique chaque jour à tous vos Concitoyens le but que vous vous êtes proposés. Présenter continuellement à la Province le tableau mouvant de son Commerce, de ses productions \& de leur prix; de sa population, de ses établissemens en tout genre, \& en offrir chaque mois des résultats exacts: donner une analyse des travaux des diverses societés littéraires de la Guienne, des ouvrages, des découvertes, des expériences, des vues utiles de chaque Citoyen; telle est la tâche pénible que vous vous êtes prescrite, \& qui, indépendamment de son utilité actuelle, est destinée à devenir la base la plus solide de $l^{\prime}$ Histoire future de cette Province. J'avouerai même que c'est sur ce dernier rapport que vos Feuilles m'ont plus particuliérement intéressé par les grands résultats qu'elles offriront à nos Historiens sur les objets qu'il leur importe le plus de connoître, \& dont nous avons été totalement privés jusqu'à ce jour, faute de pareils secours. L'état, les forces \& les lumieres d'un peuple quelconque ne peuvent s'évaluer que par des tableaux comparés de sa population, de son Commerce \& de ses Arts; \& ces tableaux ne peuvent résulter que de l'exposition journaliere des détails. (sic)

This testimony about the novelty and utility of the daily press as a medium for social and cultural history suggests that the exercise in historicizing undertaken in the following paragraphs is not far removed from contemporary sensibility.

What La Rochelle's weekly newspaper says about the city's economic and cultural relations with England in the years before and after the publication of L'Anglomanie supports the notion that the poem might well have had a firmer grasp on local and national issues. The Annonces reflects the city's trading patterns, especially its participation in the import boom after 1786 . To the extent that the newspaper evidences the wide range of imported and officially banned producer and consumer 
goods, to the extent that it also exemplifies the importation of English technology and residents, it conveys how daily life in La Rochelle was affected by English culture and testifies to the paradoxes of cultural exchange which the poet might have been expected to depict.

Readers of the Annonces before the American War of Independence learned about England's agrarian revolution and the social conflicts it aroused. An extract from the Gazette de Commerce reprinted on 8 May 1772 held English veal production up as exemplary, while an article from this journal, reprinted on 9 October 1772, smirked at the conflicts between farmers who killed gamebirds to protect their harvests and landowners who raised them for hunting, indifferent to their tenants' needs. Reprinted articles about England's marine ingenuity were common. One from the Journal Encyclopédique reported that a machine for making drinking water and biscuit was being installed into English ships and told of a new cement for sealing hulls and inhibiting woodworm (22 mai 1772). Another from the Gazette d'Agriculture praised a method for circulating fresh air below deck on both naval and merchant vessels (9 octobre 1772).

When the Rochelais poet, ten years later, called for the imitation of marine technology, he was hardly original. More surprisingly, his poem does not refer to English medicine or cosmetics, topics common in the Annonces from early days. The paper carried a piece from the Gazette d'Agriculture telling of the English discovery of a mineral water that dissolved the stone (7 août 1772) and an advert for 'taffetas d'Angleterre' from a Rochefort apothecary who recommended it for post-operative bandaging 'à l'exemple des Anglois' (23 octobre 1772). A reader advertised for an English medical text (10 septembre 1773), manifesting respect for its diagnosis and treatment that was confirmed when the Intendant brought in an English inoculator for his and the region's children (25 mars 1774) and when a reader defended inoculation with reference to London hospital practice since 1746 (5 août 1774). The Annonces took from English newspapers recipes for toothpaste to nourish gums and whiten teeth (4 juin 1773) and carried adverts from pharmacists who had directly imported from England items like Mr. Dubois's famous 'l'eau de perles,' a facial wash that removed blemishes from skin and permitted women to avoid the heavy cosmetics advocated by the Rochelais poet. In its adverts for such items as the English 'ribbon of health,' an air purifier for sick-rooms, the paper did not consider health and appearance to be distinct (24 septembre 1773; 28 janvier 1774).

Long before the poet called for the imitation of English industrialism, the Annonces accustomed readers to this phenomenon. While La Rochelle had its lead-worker who advertised his skills on 15 May 1772, a négociant a few months later offered imported English lead (18 septem- 
bre 1772), a producer good not officially sanctioned. The latent dominance of English producer and consumer goods seems evident from the facts that La Rochelle's Verrerie Royale imported coal from Newcastle (16 octobre 1772) and that English bottles made of black and white glass were also imported ( 23 juin 1775 ). When a hydrology professor produces a 'machine pneumatique à l'Angloise' in Rochefort and La Rochelle (20 septembre 1773), this evidences French imitation of English industrialism and the unreality of the supposed gap between utility and style. Appreciation of English wax for preserving and enhancing shoes, boots, harness, carriages and desks (18 juin 1773) and admiration of strong, luxurious English saddles (19 novembre 1773) confirm that function and beauty were reckoned to be reciprocal and that English industrial production overwhelmed import restrictions.

The movement of people between La Rochelle and England helps to explain this openness to English technology. One citizen, having lived five years in England, underlined his experience as a teacher and translator of English with the claim that taste for the language is 'aujourd'hui si généralement répandu en France \& dans toute l'Europe' and that its 'utilité pour le commerce \& la navigation est incontestable' (24 juin 1774). A valet to a recently deceased English lady thinks this cross-cultural experience is a special qualification to his next employer (25 février 1774), and a teacher of arithmetic in Saintes holds that his lessons in foreign exchange and accountancy should attract locals because his method has been 'tirée de l'Anglois' (4 novembre 1774).

During the War of American Independence, the Annonces does not adopt a hostility to English aesthetic culture like that of the poet. The prospectus for an engraved edition of Shakespeare makes it clear that France and England jointly need the best possible illustrated text since their histories were so involved in the playwright's times (29 mars 1776). Besides carrying literary notices for a national audience, the paper prints anecdotes concerning recent English writers, as when it tells how the famous actor, James Quin, found an ingeniously sympathetic way to pay off James Thomson's debts without offending the sensitive poet (25 octobre 1776). When carrying an advert which promotes the court-approved painting kit of Milord Sykes, the paper defies the poet's view that English aesthetic and teaching modes are not among the most advanced in Europe (15 novembre 1776).

The poet seems not to have grasped that war may strengthen cultural ties between declared enemies. La Rochelle's booksellers, in offering for sale an English-French marine vocabulary, evidence a reciprocal sense of culture and practicality (29 août 1777). Distinctions between utility and aesthetics and the displacement of English goods were not effected by the war, as is clear from an account of English varnish (4 décembre 
1778). This piece explains that the English, from necessity and taste, employ wood to enclose and decorate gardens and that their trellises and palisades in the Chinese mode are attractive all the more for being protected by varnish against rain and sun: here at the peak of the war, the Annonces says that English gardening is 'un objet d'économie.' Even when announcing the displacement of English goods, the paper validates English technical standards. M. Nadeau, a pharmacist in La Rochelle, claims to make a better toothpaste than Mr. Greenouch of England and a cosmetic finer than Mr. Dubois, the famous London chemist, but the comparative nature of his advert undermines its would-be exclusiveness (21 avril 1780). The account of Jacques Faynard, the Frenchman who invented in London a powder to counteract internal and external bleeding, is no different on this score. He may have returned to his native land to demonstrate to Vergennes and the King that his medicine has important military applications, but his patriotism is formed by his attachment to England's superior medical environment (21 juillet 1780 ).

Despite the poet's call for his neighbours to imitate English utility, there is no evidence that the American War of Independence impeded the import of industrial goods and technology. Top-quality coal from Newcastle remained available in La Rochelle (13 juin 1777), and its dyeing trade received English alum (18 mai 1781). The notice of the establishment of a factory to produce English tin, tin-plate and sheetsteel at Blanduque near St. Omer reveals the widespread desire to copy English metallurgy and to apply it the manufacture of locks (21 septembre 1781). La Rochelle's war-time openness to the English economy is attested by the range of imported goods and modes: not only was the seed of English cauliflower sold (13 février 1778) but a confectioner retailed 'véritables pastilles de Menthe d'Angleterre' made by a Paris sweetmaker (14 juillet 1780).

Although the poet held that English horses were imported for racing and gambling, his neighbours were reminded of England's fine stockbreeding and of its contribution to transportation. Notices about the suitability of English horses for coach and saddle are common (30 juin 1780). Similarly, there are adverts for excellent English hunting dogs, with which the poet must have been familiar, given his Horatian stance (5 décembre 1777). An excerpt from Nature considéré blames the French for their poor horses, charging the nation with consuming twice the number it should: if French breeding were sounder, costly foreign imports could be avoided, and, if urban luxury were curbed, so many young horses would not die from being over-ridden ( 27 novembre 1778).

The importation of riding equipment continued during the war. A typical advert stresses the quality and beauty of riding boots made of English leather and details the appeal of a riding whip with a whalebone 
and silver handle (4 avril 1777). The Annonces suggests that modes of personal wear and jewellery made of English materials or according to English style expanded considerably during the war. Paris clothiers went to La Rochelle to make and sell English undergarments and dresses (23 octobre 1778; 19 mai 1780). English ribbons of the latest taste warranted an advert to themselves (12 juin 1778), and a local cabinet-maker proudly offered sleeves and ruffles made of a material imitative of English lace ( 7 janvier 1780). Similarly, a watchmaker advertises his best golden watches as English (26 février 1779), and the most ornate and costly tobacco-holders are said to be in the English manner (10 septembre 1779).

Cultural exchange as mediated by language teaching appears not to have slowed down during the war. One English teacher in town since 1763 renews his adverts to teach English and French by principle (18 avril 1777), and an Irish priest, a newcomer, proposes a three-month course to negotiants and others, a course spending the first month on pronunciation, the second on explication of the best English prose authors, and the third on the best poets (12 mars 1779; 10 novembre 1781). In exemplifying cultural interpenetration, these teachers witness that linguistic performance and literary taste are interdependent.

The years from 1784 to 1787 when the free-trade negotiations were taking place - and in the middle of which L'Anglomanie appeared mark a development in cultural exchange between England and France on the basis of the evolution of the press: England's progressive journalistic communications advanced France's awareness of utilitarian and cultural functions. The Annonces shows that the Rochelais were exposed to the international network of enlightenment through the agency of English journalism exactly when the poet represented England as simply imperialistic. The prospectus for the Journal de Médecine Anglais sent by its editor, M. Simmons, to the Annonces explains that this journal belongs to a network of European academies fostered by Sir Joseph Banks, President of London's Royal Society. Banks is praised for founding a complete library of natural history which he makes available to European scholars. This London library houses a complete collection of medical works and of newspapers and academy memoirs from across Europe. It is hailed as the foundation of the new journal printed in Paris and Dijon and sold at La Rochelle (2 décembre 1785).

A few months later, the Rochelais could read about Le Censeur Universel Anglois, a weekly started on 9 July 1785 and patronised by the Queen. This digest of English journalism is said to present: 
le tableau successif du génie, du bel-esprit \& de l'érudition des Anglois; la Notice de leurs découvertes en tout genre, le Précis de leurs usages permanens, \& une idée de leurs Modes passagères, qui ne sont pas toujours calquées sur les nôtres.

The assumptions of this newspaper are that French journalism should recognize English cultural differences and that England is an inexhaustible source of information for the French populace. Focusing on private and public events in England, on manufacturing, commodity prices, science, ethics and entertainment including poetry, and on 'singularités anglaises,' this paper systematically promotes information about England's complex, dynamic culture (17 mars 1786).

The years of trade negotiations saw commercial exchange between England and La Rochelle growing. Shipping reports in the Annonces show that trade was becoming more various. Ingots of English lead were still imported (23 janvier 1784), but small and large barrels of high quality butter and the finest wool for mattresses became available (8 juin 1787; 30 mars 1786). The same years marked a noticeable increase in English ships carrying salt from La Rochelle to London, south-coast ports and Canada (eg. 24 février 1786; 11 mars 1787).

Before the Eden treaty, personal and domestic life in La Rochelle was affected by the importation of English flannel for clothes (18 mai 1787) and of up-to-date coloured and textured wall-papers which the importing merchant offered to hang himself (12 mars 1784). The agrarian and industrial aspects of English transportation appear to have been more widely recognised. When the Marquis de Voyer sells young mares of Normandy and English breeding, he stresses that they all come from a robust English mare (18 juin 1784). The recognition of superior English stock-breeding is a feature of adverts for selling and buying carriage and saddle horses (22 juin 1787; 10 juin 1785). The fabrication of light but strong English coaches with a large seating capacity is recognised, too (5 novembre 1784). As the following advert shows, technical refinement, durability and comfort rendered English carriages useful and desirable:

Une Voiture vraiment Anglaise, montée sur 4 ressorts, propre pour courir la poste, avec glaces, stors, \& vagistas, ayant timon \& limonière, grandes \& petites roues de rechange $\&$ harnois. (9 décembre 1785)

These years mark a difference in how French and English industry is reflected in the Annonces. One advert offering for sale French-made spinning machines with seventy spindles and of English design announces that they have been used for only a few months. It points out that the skein-winders on these machines are also of English design. Yet, this cotton factory at Cognac failed because it could not adopt English 
technology (20 avril 1787). The advertisement for an English-style brewery near Nantes urges the inferiority of French beer and brewing techniques. It declares its production methods to be wholly English although they have been proved to yield long-keeping beer that is corrupted by neither heat nor sea, tests having been carried out on board a French naval vessel in 1780 (18 juin 1784).

Before the impact of the Eden Treaty could be registered, then, signs appeared indicating the inefficacy of French industrial processes. After the Treaty became law, pent-up demand for better goods was released in La Rochelle leading to the reshaping of wholesale and retail businesses and of the habits of consumers. Warehouses were established that specialised in English goods. One at Niort which stocked a wide range of cloth and stuffs besides tin, whale oil and faience shows that inland depots began to serve the retail trade in La Rochelle's hinterland ( 25 avril 1788). In the city itself, luxury goods from England began to be imported directly. Thus, modish English furniture made of unfinished walnut became available (11 juillet 1788). Retail specialisation and competition grew rapidly because of the demand for English housewares. A month after full services of English faience were offered at St. Martin, Isle de Ré (12 octobre 1787), Madame Bourillon of La Rochelle advertised parcels of English faience, including table sets for lunch and dinner (16 novembre 1787). Two weeks later her husband announced - in addition to English faience of the latest taste - trays, crystal, razors, lamps, buckles, knives, wool and silk stockings (30 novembre 1787). Competing with a new shop vending specialty English stuffs such as calmucks, satins, velvets, cottons and mousselines (14 décembre 1787), M. Bourillon announces that he is going to sell only English goods which he ordered when visiting manufacturers. To meet the competition better, he sells off his French-made stuffs, some of which hail from Rouen, at below cost price (14 décembre 1787).

The rapid rise in English products affected La Rochelle's export trade in addition to the purchasing habits of its citizens, as evidenced by a letter from Rouen appealing to the port's armateurs to buy French rather than foreign materials (13 mars 1789). The armateurs are urged to buy cotton made in Rouen to sustain its price, the problem being that, while the price of French cotton has fallen 15\%, it is still 5\% higher than imported cotton. The desperation in the Rouen letter implies that La Rochelle's slave-traders could not afford to pass up buying and re-exporting foreign cotton and suggests that relations between the national and colonial economies were fragile. This is not to say all enterprises based on English imports succeeded. One shop, 'le Magasin de faience d'Angleterre,' stayed in business for only two months. It opened by flourishing an infinity of objects never before seen in France - made of white and coloured clays 
such as flower pots, basins, eye baths and other pieces 'de fantaisie \& d'utilité' (1 mai 1789). Ten weeks later it declared its closure, offering its goods at the lowest prices - at cost price to anyone who would buy the lot to stock an inn or tavern (10 juillet 1789). There are no clues about why the shop closed. But the closure was not due to a declining interest in English goods. Cutlery and metalware streamed into La Rochelle (28 novembre 1788), as did carriages, horses and riding equipment (8 août 1788). French designers continued to decorate superior English stoves (28 novembre 1788) and to work superb English leather into fine boots and saddles (31 octobre 1788).

La Rochelle's ties to England's material and aesthetic culture were not obviously loosened by the Revolution of 1789 . The commercial momentum of the Eden Treaty was maintained despite political changes, the city's appreciation of English utility and aesthetics being heightened by revolutionary propaganda in some instances. The newly titled Affiches show that M. Bourillon kept his English shop going by diversifying his imports to include Gloucestershire and Cheshire cheeses ( 1 janvier 1790). Producer goods such as pewter and black-lead were imported (8 juillet 1791), and iron stoves for heating greenhouses and making 'la cuisine \& la patisserie' were advertised with enthusiasm for the quality and beauty of English industrial production (7 octobre 1791; 30 juin 1792). English coaches - berlines and octans - retained their reputation for strength and beauty (12 février 1790; 26 mars 1790). Businesses which rented out carriages by the day, half-day or hour or which offered tours of town and country stressed that their vehicles were English since new democratic tastes embraced English industry ( 21 janvier 1790; 26 novembre 1790). Revolutionary consumerism was not doggedly nationalistic, as the importation of pharmaceutical goods confirms. Former wishes to displace and copy such goods seem to vanish: Stoughton's elixir and Hearn's medicine arrive in direct response to citizens' demands, being sold on commission and wrapped in paper with instructions in French (2 avril 1790). Highest quality English fabrics were still imported for clothes-makers (1 janvier 1790). In addition to English wool and cotton, hats, gloves and stockings remained available (5 novembre 1790). Fashionable dress in the latest national style and sent from Paris to be retailed by a Rochelais jeweller included English gloves (20 août 1790). The appropriation of English goods by the Revolution is nicely illustrated by the fact that the plated and engraved buttons offered to the National Guard in La Rochelle were 'en métail Anglais' (24 décembre 1790).

Leisure activities linked to English modes did not lose their aesthetic tone: five-year old billiard tables are no less excellent or desirable for being 'garnis à l'anglaise' (15 octobre 1790). English language instruction retained its appeal: a native Rochelais, having studied in Paris and spent 
several years in England, offers to teach English according to a unique method (11 juin 1790). A reader of Adam Smith's The Wealth of Nations who let the first volume slip from his coach on the road from La Rochelle to Nantes is not embarrassed to solicit the return of his English title (13 mai 1791).

Of course, in the early years of the Revolution, enmity between France and England was slow to develop. Letters from London's Society of the Friends to the Revolution, printed in the Affiches in November 1790 and May 1791, gave moral support which offset threats from conservative forces in England. Lord Stanhope's claim that England's prosperity depended on political liberty that had evolved over the centuries and his forecast that the French, having soon attained such liberty, would as quickly enjoy economic prosperity, could not have damaged the commercial and cultural ties between La Rochelle and England (12 novembre 1790). A second letter from this group to La Rochelle's Friends of the Constitution, in declaring France's heroism the basis for 'un commerce d'une fraternité mutuelle \& d'une amitié durable' between the nations, cannot have hurt prospects for continuing cultural exchanges (27 mai 1791), exchanges furthered by military and imperial rivalry. The cooption of English industry and commerce in the early Revolution shows the depth of exchanges to which the Rochelais poet's brand of militarism blinded him. He knew that both trade and resistance to trade may be surrogates for war but did not realize this paradox in his poem. His inconsistencies - his unthinking commitment to fashion and self-defeating anglophobia - invite readers to develop a paradoxical awareness of the ties between material and aesthetic culture.

Perhaps the anonymous poet adhered so tightly to traditional literary modes that he would not consult the press for a sense of his city's cultural exchanges with England. Perhaps nationalistic, social and sexual prejudices blinded him to the internationalism of the agrarian and industrial revolutions and of consumerism. Still, what L'Anglomanie and the journal in which it was advertised show is that the poet could uphold neither his distinction between utility and aesthetics nor his cultural isolationism because trade between the two nations - especially in war-time reinforced the cultural interdependence of France and England. ${ }^{3}$

\section{ROBERT JAMES MERRETT}

University of Alberta 


\section{Notes}

1 The paper is cited hereafter as Annonces. On January 1, 1790, it changed its name to Affiches de la Rochelle, ou Journal de la province d'Aunis. This title is cited as Affiches. The entry on these papers by Gilles Feyel in Sgard (1991: 43-45) is extremely helpful. These papers are now read on microfiches. I thank the staff of the Bibliothèque Municipale de La Rochelle for graciously facilitating the research on which this article is based.

2 Clark (1981) points out that manufacturing played an insignificant part in the local economy of La Rochelle (3), that state politics ruined its port (18), and that the city was always inclined towards the capital and commercial network of western Europe (23). Clark's story of La Rochelle's falling share of France's external commerce (37) and his description of business failures and of falling real estate values after the American War of Independence (107) are essential contexts for the present argument.

3 Readers interested in the relations between consumerism, the press, and literary and cultural history will find them elaborated in my article listed in Works Cited (Merrett 1994).

\section{Works Cited}

Affiches de la Rochelle, ou Journal de la province d'Aunis. La Rochelle, 1790-1792.

Annonces, affiches, et avis divers de la généralité de la Rochelle. La Rochelle, 1772-1789.

Anon. L'Anglomanie, Poëme sur les Modes, Prises des Anglois, dans les Jardins, dans les Habillemens, Ec. Ec. Ec. en l'année 1784. La Rochelle: P.L. Chauvet, 1785.

Bériac, Jean-Paul. 'Un Savant Du Siècle Des Lumières: François De Paule Latapie, 17391823 ' in Révolutions En Aquitaine De Montesquieu A Frédéric Bastiat. Actes Du XLII Congrès D'Etudes Régionales De La Fédération Historique Du Sud-Ouest. Bordeaux, 1990, 633-49.

Christie, Ian R. Wars and Revolutions: Britain, 1760-1815. Cambridge, Mass.: Harvard University Press, 1982.

Clark, John G. La Rochelle and the Atlantic Economy during the Eighteenth Century. Baltimore: Johns Hopkins University Press, 1981.

Doyle, William. The Oxford History Of The French Revolution. Oxford: Clarendon, 1989.

Grieder, Josephine. Anglomania In France 1740-1789: Fact, Fiction, And Political Discourse. Genève: Librairie Droz, 1985.

Horn, David Bayne. Great Britain And Europe In The Eighteenth Century. Oxford: Clarendon, 1967. 
Latapie, François de Paule. Journal de mon voyage d'Angleterre 2 février 1770 - 20 mars 1770. Bibliothèque Municipale de Bordeaux. MSS 1789. Inventaire No. $46.2666 / 1928$.

(trans.). L'Art De Former Les Jardins Modernes, Ou L'Art Des Jardins Anglois [Par Mr Whately]. Paris: Charles-Antoine Jombert, 1771.

Merrett, Robert James. 'The English in eighteenth-century Dijon: the provincial press, cultural exchange, and literary history,' Studies on Voltaire and the eighteenth century, 319 (1994): 403-16.

Sgard, Jean (ed.). Dictionnaire des Journaux 1600-1789. 2 vols. Paris: Universitas, 1991. 